\section{SOI: 1.1/TAS DOI: 10.15863/TAS International Scientific Journal Theoretical \& Applied Science}

p-ISSN: 2308-4944 (print)

e-ISSN: 2409-0085 (online)

Year: 2017

Issue: 07

Volume: 51

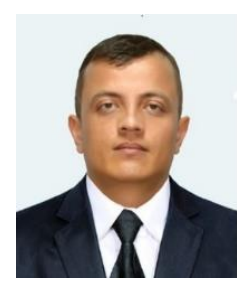

Jamshid Ganijonovich Jalilov senior scientific employee-researcher of "Marketing" department Tashkent state university of economics, Uzbekistan Phone: +998936820717 Jalilovjg@mail.ru

Published: $13.07 .2017 \quad$ http://T-Science.org

SECTION 31. Economic research, finance, innovation, risk management.

\title{
HEDONIC MOTIVATIONS AMONG UZBEK CONSUMERS
}

Abstract: The study aims to explore the hedonic motivations among Uzbek consumers. In addition, the effects of pleasure, fashion status, income level and age on the hedonic motivations are investigated. This paper uses 30 items questionnaire. The analysis is done based on 158 returned and usable questionnaires. Multivariate analysis of variance and analysis of variance are applied for this study. MANOVA results show that income level and age have different significant effects on hedonic motivations among Uzbek consumers.

Key words: Consumer Behavior, motivation, fashion status, hedonic motivation.

Language: English

Citation: Jalilov JG (2017) HEDONIC MOTIVATIONS AMONG UZBEK CONSUMERS. ISJ Theoretical \& Applied Science, 07 (51): 34-41.

Soi: http://s-o-i.org/1.1/TAS-07-51-7 Doi: crossef https://dx.doi.org/10.15863/TAS.2017.07.51.7

\section{Introduction}

The Republic of Uzbekistan in the Commonwealth of Independent State (CIS) countries was given an assessment. In the years of independence, increasing dynamics were formed of textile industry of the country and the improvement of consumer living standards, a growing wealthy middle class have attracted many national firms to Uzbek markets. Development of the domestic textile industry, Uzbek's textile market has thus become very competitive. Uzbek consumers' characteristics, however, are different from others because of the country's unique social, economic, political, and cultural environments. Uzbek consumers' unique shopping behaviors and attitudes constrain the success of some domestic companies. Profitability of the companies depend on identifying and conducting the consumer behavior. Thereupon, having better knowledge about consumer behavior will result in improving marketing decisions. Paying more attention to the reasons of buying and shopping motivations is one of the key dimensions of consumer behavior which is used in marketing. Starting from Tauber, specific shopping differences and orientations in consumers' patterns have been studied (e.g., Dawson, Bloch and Ridgway, 1990; Mooradian and Olver, 1996; Rohm and Swaminathan, 2004; Roy, 1994; Westbrook and Black, 1985, Guido, et al., 2007, Shahriar Azizi, 2011), as well as wider shopping outcomes, typically referred to utilitarian and hedonic factors (e.g.,
Ahtola, 1985; Babin, Darden and Griffin, 1994; Dhar and Wertenbroch, 2000; Kim and Kim 2008, Robert Davis et.al, 2014. Isak Barbopoulos,2015). Consumer motivation plays an important role in explaining their behaviors (Kotler and Keller,2016 ;Del I. Hawkins et al, 2010; Schiffman and Kanuk, 1997; Solomon, 2006).

Tauber (1972) argues that the customers do not always shop based on the functional and rational reasons, but also in many cases they go shopping due to hedonic reasons. Thus, in addition to hedonic motives have great effect on consumer buying behaviors. Arnold and Reynolds' (2003) classification of hedonic shopping motivation includes both nonpurchase-oriented motivationsadventure, social, gratification, and idea shopping (less likely to purchase) - and purchase-oriented motivations - role and value shopping (more likely to purchase). However, these findings have limitations, as these studies' employed settings that were mostly limited to hedonic environments such as shopping malls or places in which shoppers purchase shopping goods (e.g., fashion items) of a hedonic nature that are more likely to satisfy hedonically motivated appetites (Arnold and Reynolds 2003; Beatty and Ferrell 1998; Haytko and Baker 2004; Kim and Kim 2008; Roy1994 Swinyard1993; Wakefield and Baker 1998). The present research tries to find an answer to the following questions: Do Uzbek consumers tend toward hedonic motivation? Do demographic variables including: age, gender and 
marital status affect hedonic shopping motivation among Uzbek consumers?

\section{Literature Review}

Motives, as results of inner processes, can be unconscious and influence the behavior outside of awareness, however, they can often be made conscious by individual own reflection or by means of certain questioning techniques, especially those, which apply indirect questioning approaches (Kroeber-Riel et al., 2009; Trommsdorff, 2009).

Firstly, we should distinguish the notion of motives from notions of needs and wants which are often used as synonyms for each other.

Concept of needs exists on a different theoretical level than concept of motives. Needs are, indeed, the elicitors for motives, characterizing a level of deprivation. Motives are already explained, i.e. they are goal-oriented, while needs are not. Thus, with a real sensation of deprivation a need attains a grade of motive possessed of its defined direction (Trommsdorff, 2009).

Wants are also often used in the context without any difference to motives. Wants are on the same theoretical level as needs. While needs explaining what is really needed, wants are equally to wishes or desires. They explain what people wish to achieve or to obtain. Wants (wishes or desires) represent specific implementation of a goal that motivates consumer to buy a particular product (Lass, 2002). This indicates that motivational forces have a key influencing role in the modeling of shopping behavior, which is assumed to be goal-directed behavior. Shopping motivation, then, could be defined as the drivers of behavior that bring consumers to the marketplace to satisfy their internal needs (Jin and Kim, 2003).

If the shopping motive is solely a function of the buying motive, the decision to shop will occur when a person's need for particular goods becomes sufficiently strong to allocate time, money, and effort to visit a store. However, the multiplicity of hypothesized shopping motives suggest that a person may also go shopping when he/she needs attention, wants to be with peers, desires to meet people with similar interests, feels a need to exercise, or has leisure time. Therefore, consumers' motives for shopping are functions of many variables, some of which are unrelated to the actual buying of products. Hedonic shopping motivation are important to consumer marketers because of two reasons; first, they are means by which to attract a consumer into a store and second, they can be viewed as ways to enhance the value of the object of the hedonic motivation and thus operate as sources of sustainable competitive advantage (Parsons, 2002).

As it mentioned before, Tauber (1972), in his exploratory study found that securing a purchase was not the only motive for shopping. Subsequently he identified 11 shopping motives and divided them into personal and social motivation. Personal motives are related to the person's state and moods; and social motives are associated with others and community. Tauber (1972) identified personal motives as role playing, diversion, self- gratification, learning about new trends, physical activity, sensory stimulation communication with others having a similar interest, peer group attraction, status and authority and pleasure of bargaining.

Westbrook and Black (1985) reported that 'shopping behavior may arise (1) principally to acquire the desired product for which needs are experienced; (2) both to acquire the desired product and to provide satisfaction for various additional nonproduct related needs; or (3) principally in service of needs unrelated to the acquisition of the product; these researchers identified seven motivation based on aforesaid classification. These motives are: anticipated utility (expectation of benefits or hedonistic states which will be provided by the product to be acquired through shopping), role enactment (culturally prescribed roles regarding the conduct of shopping activity, such as careful price and product comparisons), negotiation (motivation to seek economic advantages through bargaining interactions with sellers), choice optimization (desire to buy the "absolute optimum" and seeking to find a product that fits to consumer demand), affiliation (motivation to affiliate with friends, other shoppers, or retail merchants), power and authority (trying to achieve a sublime social status) and stimulation (seeking interesting stimuli in shop environment such as music and staining ). Paying more attention on Westbrook and Black classification, this point becomes clear that unlike Tauber's taxonomy, in Westbrook and Black classification the utilitarian and hedonic motives are not completely separated from each other; and some of mentioned motivations are a combination of both utilitarian and hedonic motives. Arnold and Reynolds (2003) introduce six types of hedonic motivations related to a shopping behavior. In their viewpoint, shopping motives are: adventure shopping (buying is considered as an adventure activity which refers to shopping for stimulation, adventure, and the feeling of being in another world), social shopping (buying is an opportunity for socialization),gratification shopping (a third category is labeled "gratification shopping," which involves shopping for stress relief, shopping to alleviate a negative mood), idea shopping (it refers to shopping to keep up with current market trends and new fashions and to see new products and innovations), role shopping (buying is a role playing via consumers), value shopping (it alludes to shopping for sales, looking for discounts and hunting for bargains).

A hedonic shopping motivation is characterized by an emotional state (Guido, et al., 2007). "It might be argued that consumers behaving hedonically shop 
more frequently: they are explorative, they enjoy it, and may continue shopping even in the absence of a specific need for a certain product." (Scarpi, 2006) As fashion is used more and more as a form or art and a way to express our internal personalities and individuality, we as consumers have turned clothing shopping into a hedonic purchase. We search for apparel that stimulates our aesthetic senses. Some women and men even use apparel shopping as therapeutic relief, sending their mind into a state of joy while they shop for clothing appealing to their wants and likes. Consumers behaving hedonically could be attracted to fair trade clothing because it makes a personal statement, it is considered the new wave of consumerism, and it allows the consumer to explore new places to purchase these garments.

"By nature people are motivated to enjoy themselves" (Okada, 2005). People enjoy themselves when they feel good about themselves. "...What we need to understand is that emotion drives the consumer and while it is an intangible, highly individualistic thing, it controls the consumer when they shop"(Danziger, 2006). Purchasing a stylish product could stimulate many internal good feelings; being socially responsible, obtaining self gratification, appealing to personal taste, etc. "Hedonism has been measured using Babin's et al. (1994) scale, asking consumers how much fun they had during the shopping trip, if they had a good time while shopping, if they enjoyed being immersed in new products, and if they enjoyed shopping per se." (Scarpi, 2006) A consumer buying stylish goods because they enjoy the act of shopping and what comes with it would be fulfilling a pleasurable motivation, or hedonic motivation. The shopping motivation literatures underline the existence of large differences between utilitarian and hedonic motivation, but both of them have an effect on the decision of consumer buying simultaneously. We divide hedonic motivations into two dimensions;

\section{Pleasure seeking}

If a consumer purchases stylish products and they know they are assisting to cease sweatshop production, and by doing an ethical act it could make the consumer feel good about their social standing. "After consumers put effort into the acquisition of hedonic goods, they believe that they have earned the right to indulge and thus become more likely to consume. Bundling a hedonic purchase with a promised contribution to charity reduces the sense of guilt and facilitates hedonic purchases." (Okada, 2005) Hedonic clothing consumers are purchasing this ethical apparel because of the end result the consumer feels. "Need most often sends out to the store, while desire plays a dominant role in getting us to make purchases" (Danziger, 2006). Many consumers often shop for therapeutic reasons; they enjoy the act of shopping and the recreation. Shopping for clothes is often seen as therapeutic for some consumers. If a consumer can justify their need to want to shop by supporting a socially responsible cause, the sense of guilt of wanting to shop is relieved and the consumer is more motivated to purchase a fair trade item. Shopping to satisfy this emotion will be considered being motivated by the recreational dimension of hedonic behavior for this study. Often times, since hedonic motivations are an emotional state, a justifier is needed to make the purchase. Justifiers turn desires into needs. "...The ultimate justifier that transforms want into need is how a particular purchase will ultimately enrich the quality of one's life" (Danziger, 2006). Consumers purchasing fair trade clothing with a hedonic motivation are justifying their purchase by using the belief that their purchase is helping another person, thus making the consumer's quality of life better, by touching their emotional state. Price can often times become a barrier for purchasing stylish clothing. "Moreover, emotion helps interpret price, either by making the shopper feel excited about finding a bargain or willing to stretch their budget to pay a price high than they would like" (Danziger, 2006). Hedonic consumers can justify the price of stylish clothing as a purchase that adds to their perception of themselves as an ethical consumer. This gives the consumer an obtained social status, tangible or tangible; motivated by the self gratification dimension of hedonism.

As individuals, we constantly seek acceptance from ourselves and other. If a consumers peers value social responsibility, being seen buying or wearing stylish products will support this social status. "As Shaw and Shiu have shown, the issue of "selfidentity" is crucial to consumers' decisions to privilege stylish products in their consumption choices. In other words, they say, many people who become stylish consumers do so because they believe that it is something that people like them should do: that is, people of their social background, their organizational affiliation and their political orientation." (Watson,2006) Shopping stylish clothing to obtain a social status is again motivated by self gratification and a feeling of pleasure internally. The image associated with stylish clothings relates not only to the lifestyle that consumers can buy for themselves, as it does in conventional advertising, but also to the sense of using consumption choices in order to do the right thing by distant strangers.

\section{Fashion Status}

In the general context of clothing, consumers are often motivated by the styling characteristics and their personal taste for fashion. Consumers 
shopping according to style are satisfying their senses. A consumer may buy clothing not because of deep-rooted beliefs, but because the garment fits and flatters their body.

"In clothing choice, research has revealed that factors including fashion and availability are pertinent to actual purchase behavior among concerned consumers." (Shaw, et al., 2006) This concern if often found in younger consumers worried about fashion status. These consumers often buy what looks good on them. "This was evident from complaints about the 'unfashionability' of many stylish alternatives available on the market." (Shaw, et al., 2006) Styling feature and aesthetic appeal matter vary much to a consumer that is hedonically motivated. A consumer is shopping based on their personal wants. "We must not forget the importance of desirable clothes. For smaller ethical retailers to gain a presence on the high street, they will need to leave behind clichéd staples such as shapeless hemp tunics and make clothes that people want to wear." (Shepard, 2010) Selespersons have answered consumer demand for fashionable products by seeking out the fair trade apparel that has "trendy", or in style, characteristics about the garments. Stylish product has been considered fashionable and part of the new wave of consumerism by numerous researchers. “...hedonism could be easily evoked by being immersed in many new products, by the curiosity of seeing and trying new clothes and accessories." (Scarpi, 2006) Consumers can be intrigued by this new world in fashion and are curious about the products. "A consumer immersed in an atmosphere favoring hedonic feelings, such as a typical fashion store, could be more likely to act on the spur of the moment, to explore, to try, and thus to do unplanned purchases." (Scarpi, 2006) Consumer may find themselves purchasing modern clothing because it is the new trend in fashion, a socially responsible trend to follow. These are people fashion followers, the vast majority of clothing consumers, look up to for new trends in fashion to follow.

\section{Demographics affecting hedonic motivations}

Another common way retailers categorize their consumers are based on demographic information. Younger consumers shop differently for various products than older consumers. The same can be said for any differentiation among demographic groups. H1-H4, addresses age and income-level of clothing consumers. These two demographic groups were chosen to examine based on suggestions from previous literature. Numerous authors suggest that age and income-level play a determining role in consumer characteristics of purchasing clothing.

\section{Age}

Apparel and clothing accessories are often forms of outlet to favor distinctive products for young age group. Young age group of female and male alike could be drawn to this intriguing side of fashion. By wearing stylish clothing young age group of female and male are able to make themselves distinctive among peers. One way to exhibit uniqueness is through wearing apparel that displays individuality or by acquiring exclusive consumer products. With the lack of stylish clothing compared to the easily accessible mainstream clothing, stylish clothing can be viewed as exclusive consumer products. Consumers who perceive a greater need for self-uniqueness are likely to try a new trend and actively seek out new clothing styles. Younger consumers will be more hedonically motivated to purchase clothing.

In authors Becchetti and Rosati's (2007) study, they indicated that social media, current educational system, or having knowledge and access to the internet and allowing for worldly views to be widely spread. (Littrell, 2005) This shows promising hedonic motivations. "For their actual product behavior, they were less likely to wear ethnic clothing but more likely to wear fashionable attire. As for socio-political values, the youngest group of respondents' participation as community activists was more limited than baby boomers and swing."

Therefore it is hypothesised that:

$\mathrm{H1}$ : Pleasure seeking hedonic shopping motivation has a significant effect on among age groups of uzbek consumers.

H2: Fashion Status hedonic shopping motivation has a significant effect on among age groups of uzbek consumers.

\section{Income Level}

"Higher prices simply place ethical items beyond the means of some consumers, while others would appear to balance the extra cost against the purpose of the clothing." (Shaw, et al., 2006) Consumers that feel that purchasing stylish clothing is the right thing to do, and feel that their purchase is making a difference, will typically not let price get in the way, supporting Becchetti and Rosati's results. "It might in fact be argued that consumers behaving hedonically buy more items, as they indulge in impulsive buying. On the other hand, the goods usually considered in the literature on impulsive buying tend to be low-priced items, so that utilitarian behaviour may lead to higher spending." (Scarpi, 2006). Therefore it is hypothesised that: 


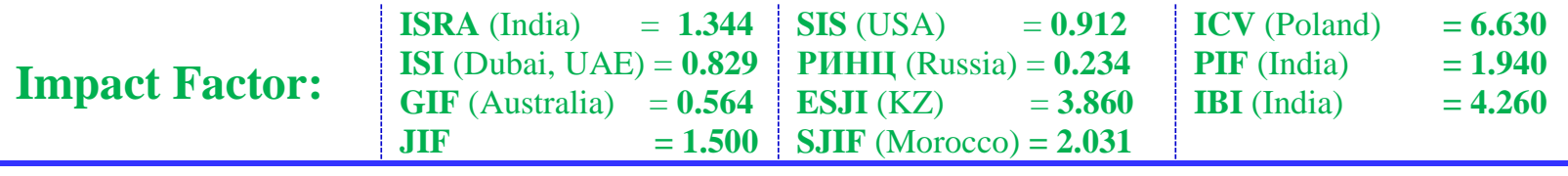

H3: Pleasure seeking hedonic motivation has a significant effect on income level of uzbek consumers.

H4: Fashion Status hedonic motivation has a significant effect on income level of uzbek consumers.

\section{Research Methodology}

- Sample

The sampling of the present study is drawn from the students of the Tashkent state university of economics. Out of 165 distributed questionnaires, 158 useful ones were returned (a response rate of 95.7 percent). 7 returned questionnaires were omitted because of missing data. Hence, finally the analysis is done on 158 usable questionnaires.

\section{- Measures}

For measuring hedonic motivation, we used five-point Likert scale (completely disagree $=1$, disagree $=2$, neutral $=3$, agree $=4$, completely agree =5). 30 questions fitted to the Tauber as well as 10 hedonic motivations according to Pleasure and fasion status were designed. Cronbach's alpha for scales was 0.878 , which suggested that the measures for the scales were reliable. Four questions were considered for measuring demographic variables including: gender, age, income level and marital status.

Table 1

\section{Classification of hedonic motivations.}

\begin{tabular}{|c|c|c|}
\hline Category & $\begin{array}{l}\text { Hedonic } \\
\text { motivations }\end{array}$ & Items \\
\hline \multirow[t]{5}{*}{$\begin{array}{l}\text { Pleasure } \\
\text { seeking }\end{array}$} & $\begin{array}{l}\text { Communication } \\
\text { With others having a } \\
\text { similar Interest }\end{array}$ & $\begin{array}{l}\text { 1. I enjoy talking to other shoppers } \\
\text { 2. I enjoy talking with other consumers and salespeople } \\
\text { 3. Salespeople are kind } \\
\text { 4. I can talk with salespeople who advise me }\end{array}$ \\
\hline & Self-Gratification & $\begin{array}{l}\text { 1. I enjoy going shopping just to pamper myself } \\
\text { 2. It's especially fun to buy "impulse" items } \\
\text { 3. I enjoy anonymity }\end{array}$ \\
\hline & Physical Activity & $\begin{array}{l}\text { 1. I enjoy going to the store just to walk } \\
\text { 2. Shopping gets me up and doing something physically active }\end{array}$ \\
\hline & $\begin{array}{l}\text { Sensory } \\
\text { Stimulation }\end{array}$ & $\begin{array}{l}\text { 1. I enjoy looking at store displays } \\
\text { 2. I enjoy the hustle and bustle of stores } \\
\text { 3. Stores are exciting places to visit }\end{array}$ \\
\hline & $\begin{array}{l}\text { Pleasure of } \\
\text { Bargaining }\end{array}$ & $\begin{array}{l}\text { 1. I love to hunt for bargains } \\
\text { 2. It's important to me to be a smart shopper } \\
\text { 3. I enjoy to save money by shopping in store }\end{array}$ \\
\hline \multirow[t]{5}{*}{$\begin{array}{l}\text { Fashion } \\
\text { Status }\end{array}$} & $\begin{array}{l}\text { Social experiences } \\
\text { Outside the home }\end{array}$ & $\begin{array}{l}\text { 1. Sometimes I shop just to be around other people } \\
\text { 2. Shopping is an opportunity for social interaction } \\
\text { 3. I like meeting people while shopping }\end{array}$ \\
\hline & $\begin{array}{l}\text { Peer Group } \\
\text { Attraction }\end{array}$ & $\begin{array}{l}\text { 1. I like to shop with my friends } \\
\text { 2. I enjoy "hanging out" with friends at the store } \\
\text { 3. Shopping's a good way to spend time with friends }\end{array}$ \\
\hline & Diversion & $\begin{array}{l}\text { 1 Shopping is a good excuse to get out of the house } \\
\text { 2. I only shop when I have to buy something } \\
\text { 3. I can go shopping every hour of the day }\end{array}$ \\
\hline & $\begin{array}{l}\text { Learning About } \\
\text { New Trends }\end{array}$ & $\begin{array}{l}\text { 1. I often browse just to keep up with new products on the store } \\
\text { 2. I often shop to keep up with the latest trends } \\
\text { 3. I like to visit new stores to see what they have to offer }\end{array}$ \\
\hline & $\begin{array}{l}\text { Status and } \\
\text { Authority }\end{array}$ & $\begin{array}{l}\text { 1. I like the personal attention I get at better stores } \\
\text { 2. I like being "pampered" by attentive salespeople } \\
\text { 3. I wish salespeople were more attentive and respectful }\end{array}$ \\
\hline
\end{tabular}

Source: Adapted from Tauber, E.M . And Westbrook, R.A., Black, W.C.

\section{Analysis Strategies}

In this study, for examining the impact of demographic variables on buying hedonic shopping motives, a one-way between-groups multivariate analysis of variance (MANOVA) and analysis of variance (ANOVA) are performed. 


\begin{tabular}{|c|c|c|c|c|c|c|}
\hline Impact Factor: & $\begin{array}{l}\text { ISRA (India) } \\
\text { ISI (Dubai, UAF } \\
\text { GIF (Australia) } \\
\text { JIF }\end{array}$ & $\begin{array}{l}=1.344 \\
=0.829 \\
=0.564 \\
=1.500\end{array}$ & $\begin{array}{l}\text { SIS (USA) } \\
\text { PИНЦ (Russia) } \\
\text { ESJI (KZ) } \\
\text { SJIF (Morocco) }\end{array}$ & $\begin{array}{l}=0.912 \\
=0.234 \\
=\mathbf{3 . 8 6 0} \\
=\mathbf{2 . 0 3 1}\end{array}$ & $\begin{array}{l}\text { ICV (Poland) } \\
\text { PIF (India) } \\
\text { IBI (India) }\end{array}$ & $\begin{array}{l}=6.630 \\
=1.940 \\
=4.260\end{array}$ \\
\hline
\end{tabular}

\section{Results}

- Age

MANOVA results for age show that there is statistically significant difference between different age groups on the non-functional shopping motives $[\mathrm{F}(4,153)=1.693, \quad \mathrm{p}=.009$; Willks' Lambda $\left.=.854 ; \eta^{2}=.052\right]$ and the fasion status shopping motivations $[\mathrm{F}(4,153)=1.671, \mathrm{p}=.008$; Willks' Lambda $\left.=.854 ; \eta^{2}=.05\right]$. When the results for the dependent variables are considered separately, Ten differences are observed using a Bonferroni adjusted alpha level of 0.016. An interesting result indicates that among these hedonic shopping motivations, the persons aged 60 and over scored significantly higher than other age groups. In other words, comparing the mean scores of the motives of physical activity $[\mathrm{F}(4,153)=1.86, \quad \mathrm{p}=$ $\left..01 ; \eta^{2}=.018\right]$, Social experiences Outside the home $\left[F(4,153)=1.48, p=.02 ; \eta^{2}=.015\right]$, learning about new trends $\left[F(4,153)=1.096, p=.04 ; \eta^{2}=.01\right]$, communication with others having a similar interest $\left[F(4,153)=3.29, p=.00 ; \eta^{2}=.029\right]$ and peer group attraction $\left[\mathrm{F}(4,153)=1.28, \mathrm{p}=.03 ; \eta^{2}=.013\right]$ to the different age groups illustrate that people aged 60 and over score significantly higher than other age groups. That shows the high effect of hedonic shopping motives on elderly consumers; the causes are shopping can provide old mans with a considerable amount of exercise they do not feel weary. people that aged 60 and over are a lonely persons; hence, go shopping provide themselves to find and interact with the people in the same interest or shopping due to join to a favorite peer group. And because of their high amount of free times, shopping can entertain them or they can accept some duty household shopping.

The young people aged 21 to 30 score significantly higher than other age groups in the motives of sensory stimulation $[\mathrm{F}(4,153)=1.52, \mathrm{p}$ $\left.=.03 ; \eta^{2}=.015\right]$ and status and authority $[\mathrm{F}(4,153)$ $\left.=1.62, p=.02 ; \eta^{2}=.016\right]$. It indicates the importance of showing high status and good economic station to the others for youngsters. And also, well design,colorful showcases and other sensory stimulation can attract youngsters more than other age groups. Our findings about age support the hypothesis $\mathrm{H} 1$ and $\mathrm{H} 2$. There is significant to the hedonic shopping motivations between different age groups.

\section{- Income level}

MANOVA results show that there is statistically significant difference between income level of people on the Pleasure seeking motivations $[\mathrm{F}(3,154)=1.78, \mathrm{p}=.001 ;$ Willks' Lambda=.796; $\left.\eta^{2}=.062\right]$ and fasion status shopping motivations [F $(3,154)=1.92, \mathrm{p}=.001$; Willks' Lambda $=.798$; $\left.\eta^{2}=.091\right]$. When the results for the dependent variables are considered separately, all the nonfunctional motives are different using a Bonferroni adjusted alpha level of .015 . Interestingly, the results show that among these 10 hedonic shopping motivations, the persons who live at the nouth of the town score significantly higher than other region in all hedonic shopping motives. In other words, comparing the mean scores of the motives of peer Group Attraction $\left[\mathrm{F}(3,154)=1.81, \mathrm{p}=.011 ; \eta^{2}=\right.$ $.019]$, learning about new trends $[\mathrm{F}(3,154)=2.34$, $\left.\mathrm{p}=.00 ; \eta^{2}=.034\right]$, Diversion $[\mathrm{F}(3,154)=2.16, \mathrm{p}=$ $\left..01 ; \eta^{2}=.021\right]$, self-gratification $[F(3,154)=1.254, p$ $\left.=.02 ; \eta^{2}=.013\right]$ communication with others having $\mathrm{a}$ similar interest $\left[\mathrm{F}(3,154)=2.305, \mathrm{p}=.01 ; \eta^{2}=\right.$ .03], status and authority $[\mathrm{F}(3,154)=4.719, \mathrm{p}=$ $\left..00 ; \eta^{2}=.047\right] \quad$, pleasure of bargaining $\left[F(3,154)=7.54, p=.00 ; \eta^{2}=.075\right]$, sensory stimulation $\left[\mathrm{F}(3,154)=2.337, \mathrm{p}=.00 ; \eta^{2}=.033\right]$ and physical Activity $\left[\mathrm{F}(3,154)=2.371, \mathrm{p}=.00 ; \eta^{2}=\right.$ .037] to the different region, illustrate that people who settle in south of the town, score significantly higher than other regions. Low income people usually try to show a good level of social class to others so shopping provides them a chance for them to do so. Our findings about income level of people support the hypothesis $\mathrm{H} 3$ and H4. There is significant to the hedonic shopping motivations between different income level of people.

\section{Conclusion and Managerial Implications}

Demographic factors have been the subject of numerous studies as one of the key factor on consumer behavior; like, Walsh and Mitchell's (2004) research on investigating demographic characteristics of the consumers who experience difficulty in making their buying decisions. In addition, in the research of Hyun-Joo Lee et al. (2010), the relationships among demographic factors (gender, age, education and income), consumer traits (technology anxiety, need for interaction, and technology innovativeness) and intention to use retail self-checkouts is explored; the results demonstrate that demographic factors indirectly influence intention to use retail selfcheckouts through consumer motivations.

As it mentioned before, there are some studies that focus on the relationship among demographic variables and consumer behavior. However, there has been no research to investigate the effect of age groups and income 
level of consumers on hedonic shopping motivations. And then because of determinant effect age and income level of consumers on hedonic shopping motives, this survey attemptes to identify the effect of age, and income level on hedonic hopping motives. In the following some conclusion are written.

Paying attention to the mean scores of each hedonic motivation indicates that people score each item of hedonic shopping motivations almost below average. This point indicates that probably in Uzbek consumer's mind, utilitarian motives are much more important than hedonic motives. Therefore, paying attention to the hedonic motives in advertisement is not more effective; although, for better assessment of the importance of utilitarian and hedonic motives in Uzbek opinion, more studies should be done.

Also, the results of this survey demonstrate that youngsters pay attention to the sensory stimulation and fasion status while shopping more than other age groups. Therefore, by well design decorating and scent, colorful showcases products, retailer can attract young people more than before.

An interesting finding here is that the severity of hedonic motives in high income consumer is much more than another, so that all the hedonic motives items are stronger in high income consumer than another, or at least equal. Therefore, emphasized on hedonic dimensions of a product and shopping process for the particular products that relate to young consumers are effective marketing strategy.

\section{Research limitations}

Finally, some limitations of this study should be mentioned. Firstly, the study sample was limited to the consumers living in Bukhara. Compared to Uzbek national population statistics, the respondents were relatively younger and better educated. Although this age and income level of consumers reflected the characteristics of the consumers of Bukhara region, the results cannot be generalized to all Uzbek consumers.

Secondly, it is reasonable that the hedonic motivations for buying one particular products is different from buying another product type but this study investigate the shopping motives generally not specified product categories and the respondents were not asking about a particular product; hence, they told their idea about shopping in a whole.

\section{Future research}

This research investigates only the impact of hedonic motivations through age and income level demographic characteristics, due to having better evaluation of the effect of hedonic motivations on consumer behaviors. It suggests measuring the utilitarian and hedonic motivation simultaneously.

Considering the limitations of this research, measuring these two kinds of motives in different types of goods and comparing them will be interesting. And also, future studies should investigate the different drivers of hedonic shopping motivation dimensions to improve understanding of hedonic motives.

\section{References:}

1. Ahtola OT (1985) "Hedonic and utilitarian aspects of consumer behavior: an attitudinal perspective", Advances in Consumer Research, Vol 20. 7-10.

2. Arnold MJ, Reynolds KE (2003) "Hedonic shopping motivation", Journal of Retailing, 79(2): 77-95.

3. Babin BJ, Darden WR, Griffin M (1994) "Work and/or fun: measuring hedonic and utilitarian value", Journal of Consumer Research, 20: 644-56.

4. Beatty SE, Ferrell ME (1998) Impulse buying: modeling its precursors. Journal of Retailing, 74(2), 169-191.

5. Becchetti L, Rosati FC (2007) “Global social preferences and the demand for socially responsible products: empirical evidence from a pilot study on fair trade consumers", The World Economy, Vol. 30 No. 5. 807-836.

6. Danziger PN (2006) Shopping. Chicago: Kaplan Publishing.

7. Dawson A, Bloch PH, Ridgway NM (1990) "Shopping Motives, Emotional Estates, and Retail Outcomes", Journal of Retailing, 66 (4), 408-427.

8. Del I. Hawkins, David L. Mothersbaugh (2010) Consumer behavior: building marketing strategy / - 11th ed. USA.: McGrawHill/Irwin,New York, 360

9. Guido G, Capestro M, Peluso AM (2007) Experimental analysis of consumer stimulation and motivational states in shopping 


\begin{tabular}{|c|c|c|c|c|c|c|}
\hline Impact Factor: & $\begin{array}{l}\text { ISRA (India) } \\
\text { ISI (Dubai, UAE } \\
\text { GIF (Australia) } \\
\text { JIF }\end{array}$ & $\begin{array}{l}=1.344 \\
=0.829 \\
=0.564 \\
=1.500\end{array}$ & $\begin{array}{l}\text { SIS (USA) } \\
\text { PИНЦ (Russia } \\
\text { ESJI (KZ) } \\
\text { SJIF (Morocco }\end{array}$ & $\begin{array}{r}=\mathbf{0 . 9 1 2} \\
=\mathbf{0 . 2 3 4} \\
=\mathbf{3 . 8 6 0} \\
=\mathbf{2 . 0 3 1}\end{array}$ & $\begin{array}{l}\text { ICV (Poland) } \\
\text { PIF (India) } \\
\text { IBI (India) }\end{array}$ & $\begin{array}{l}=6.630 \\
=1.940 \\
=4.260\end{array}$ \\
\hline
\end{tabular}

experiences. [Article]. International Journal of Market Research, 49(3), 365-386.

10. Haytko DL, Baker J (2004) It's all at the mall: exploring adolescent girls' experiences. Journal of Retailing, 80(1), 67-83.

11. Isak Barbopoulos, Lars-Olof Johansson (2016) A multi-dimensional approach to consumer motivation: exploring economic, hedonic, and normative consumption goals Journal of Consumer Marketing 33/1. 75-84

12. Kim H, Kim Y (2008) Shopping enjoyment and store shopping modes: the moderating influence of chronic time pressure. Journal of Retailing and Consumer Services, 15(5), 410419.

13. Kroeber-Riel, W., Weinberg, P. and GröppelKlein, A. (2009), Konsumentenverhalten, 9. Aufl., München: Vahlen 175

14. Lass, D. (2002), Kundenwunsche analysieren und verstehen: Theorien, Methoden und Anwendungsbeispiele fur Wissenschaft, Marktforschung- und Managementpraxis, Berlin: Berliner Beitrage zur Marketingforschung 593

15. Littrell, M. A., Ma, Yoon Jin, Halepete, Jaya. (2005). Generation X, Baby Boomers, and Swing: marketing fair trade apparel. Journal of Fashion Marketing and Management, 9(4), 407-419.

16. Michael Solomon, Gary Bamossy, Soren Askegaard and Margaret K. Hogg Consumer behaviour.A European Perspective Pearson Education, Inc. U.K.2006

17. Mooradian, T.A. and Olver, J.M. (1996), "Shopping Motives and the Five Factor Model: An Integration and Preliminary Study", Psycological Reports, 78, 579-592.

18. Okada EM (2005) Justification Effects on Consumer Choice of Hedonic and Utilitarian Goods. Journal of Marketing Research (JMR), 42(1), 43-53.

19. Parsons AG (2002) "Non-functional motives for online shoppers: why we click". Journal of Consumer Marketing, Vol.19 No.5. 380-392.

20. Philip Kotler, Kevin Lane Keller (2016) Marketing Management, 15th edition. Pearson Education, Inc. U.K.

21. Rohm AJ, Swaminathan V (2004) "A typology of online shoppers based on shopping motivations," Journal of Business Research, Vol. 57, No. 7. pp. 748-757

22. Robert Davis, Bodo Lang, Josefino San Diego (2014) How gender affects the relationship between hedonic shopping motivation and purchase intentions? Journal of Consumer Behaviour, J. Consumer Behav. 13:18-30

23. Roy A (1994) "Correlates of Mall Visit Frequencies," Journal of Retailing, 70, 39-161.

24. Scarpi D (2006) "Fashion Stores between fun and usefulness", Journal of Fashion Marketing and Management," Vol. 10, Issue 1. 7-24

25. Schiffman B, Kanuk W (1997) Consumer Behavior, Singapore: Prentice Hall.

26. Shahriar Aziz, Amir Shariffar (2011) Nonfunctional shopping motives among iranian consumers Management\&Marketing, volume IX, issue $2 / 2011$

27. Shaw D, Hogg G, Wilson E, Shui E, Hassan L (2006) Fashion victim: the impact of fair trade concerns on clothing choice. Journal of Strategic Marketing, 14(4), 427-440.

28. Shepard A (2010) Every girl's new must-buy? Eco-logical fashion. Women's Wear Daily, May 31, 2010.

29. Swinyard WR (1993) The effects of mood, involvement, and quality of store experience on shopping intentions. Journal of Consumer Research, 20(2), 271-280.

30. Tauber EM (1972) "Why Do People Shop?" ,Journal of Marketing, 31(4): 37-42.

31. Trommsdorff V (2009): Konsumentenverhalten, 7. Auflage, Verlag Kohlhammer, Stuttgart.108.

32. Wakefield KL, Baker J (1998) Excitement at the mall: determinants and effects on shopping response. Journal of Retailing, 74(4), 515-539.

33. Walsh G, Mitchell V (2004) "Demographic characteristics of consumers who find it difficult to decide", Marketing intelligence \& planning, 23(3): 281-295

34. Watson M (2006) Towards a Polanyian Perspective on Fair Trade: Market-based Relationships and the Act of Ethical Consumption. Global Society, 20(4), 435-451.

35. Westbrook RA, Black WC (1985) "A motivation-based shopper typology" Journal of Retailing, 61: 78-103.

36. Wilkie WL (1994) Consumer Behavior, $3^{\text {rd }}$ edition. New York: John Wiley \& Sons 